\title{
Çocuklukta ve Ergenlikte Mevcut ve Arzu Edilen Baba Katılım Algısı Ölçekleri’nin Türkçe Uyarlaması: Geçerlik ve Güvenirlik Çalışması ${ }^{1}$
}

\section{Adaptation of Reported and Desired Father Involvement in Childhood and Adolescence Scales to Turkish: A Validity and Reliability Study}

\author{
Özüm Seda Duran ${ }^{1 *}$, Gül Şendil ${ }^{2}$ \\ ${ }^{1}$ Uzm. Gelişim Psikoloğu, MEB, sedaozum@gmail.com, orcid.org/ 0000-0002-4457-2161, *Sorumlu Yazar \\ ${ }^{2}$ Prof. Dr. İstanbul Ticaret Üniversitesi, İnsan ve Toplum Bilimleri Fakültesi, Psikoloji Bölümü, \\ tgsendil@ticaret.edu.tr, orcid.org/0000-0002-7058-1862
}

Geliş tarihi/Received : 26.04.2021 Kabul tarihi/Accepted: 09.10.2021 Yayın tarihi/Published: 30.12.2021

\section{ÖZET}

Bu araștırmanın amacı Finley ve Schwartz (2004) tarafından geliştirilen Çocuklukta ve Ergenlikte Mevcut Baba Katılım Algısı Ölçeği ile Çocuklukta ve Ergenlikte Arzu Edilen Baba Katılım Algısı Ölçeklerinin Türkçeye uyarlanmasıdır. $\mathrm{Bu}$ amaç doğrultusunda ölçeğin dil, yapı geçerliği ve güvenirlik analizleri test edilmiştir. Çalışmanın örneklemini 18-29 yaş aralığında, yaş ortalaması 21,56 ( $\mathrm{S}= \pm 1,8)$ olan; ailesi evli ve birlikte yaşayan; 152 kadın, 135 erkek olmak üzere, toplam 287 üniversite öğrencisi oluşturmuştur. Araştırmada kullanılan veriler Kişisel Bilgi Formu, Baba Katılım Ölçeği, Çocuklukta ve Ergenlikte Mevcut Baba Katılım Algısı Ölçeği, Çocuklukta ve Ergenlikte Arzu Edilen Baba Katılım Algısı Ölçeği aracılı̆̆ıyla elde edilmiştir. Çocuklukta ve Ergenlikte Mevcut Baba Katılım Algısı ve Çocuklukta ve Ergenlikte Arzu Edilen Baba Katılım Algısı Ölçeklerinin yap1 geçerliğini ölçmek için oblik döndürme yönteminin kullanıldığı açımlayıcı faktör analizi yapılmıştır. Açımlayıcı faktör analizinin ardından elde edilen yapıların uyum değerlerini karşılaştırmak amacıyla yapısal eşitlik modeli kapsamında doğrulayıcı faktör analizi yapılmıştır. Ölçeklerin ölçüt geçerliği ve test tekrar test korelasyonları için Pearson momentler çarpımı korelasyon analizi kullanılmış, güvenirliğiyle ilgi olarak Cronbach alfa iç tutarlılık katsayısı hesaplanmıştır. Bu analizler neticesinde orijinal ölçekler 20 maddeden oluşurken Çocuklukta ve Ergenlikte Mevcut Baba Katılım Algısı Ölçeğinin 16 maddeli, Araçsal Katılım ve Duygusal Destekleyici Katılım olmak üzere iki faktörüyle geçerli ve güvenilir olduğu görülmüştür. Çocuklukta ve Ergenlikte Arzu Edilen Baba Katılım Algısı Ölçeği için de 18 maddeli, Araçsal Arzu Edilen Katılım, Duygusal Destekleyici Arzu Edilen Katılım ve Özerkleştirici Arzu Edilen Katılım olmak üzere üç faktörüyle geçerli ve güvenilir olduğu sonucu elde edilmiştir.

Anahtar Kelimeler: Baba katılım, arzu edilen baba katılım, geçerlik-güvenirlik, ölçek, baba

\begin{abstract}
The main purpose of this study is to test the validity and reliability of Father Involvement Scales (Reported Involvement and Desired Involvement Scale) developed by Finley and Scwartz (2004) and adapt them into Turkish. These scales measure two levels of father involvement as Reported Father Involvement and Desired Father involvement retrospectively for adolescent and adult children. The sample of this study consisted of 287 university students including 152 females and 135 males aged between 18-29 $(\mathrm{M}=21,56, \mathrm{SD}= \pm 1,8)$. All the participants were from intact families. The data was gathered through The Personal Information Form, Nurturant Fathering Scale, Reported Father Involvement Scale, Desired Father Involvement Scale. Exploratory factor analyses and confirmatory factor analyses were conducted and Cronbach's alphas were estimated for all scores in order to test the validity and reliability of these scales. High internal consistency estimates were obtained for both father involvement scales and based on these factor analytic results two subscales (instrumental Involvement and Expressive Involvement) were produced with 16 items for Reported Father Involvement Scale and three subscales (desired intsrumental involvement, desired expressive involvement, desired autonomizing involvement) were produced with 18 items for Desired Father Involvement Scale. In conclusion, the results indicate that Reported and Desired Father Involvement Scales are valid and reliable for this sample.
\end{abstract}

Keywords: Father involvement, desired father involvement, reliability-validity, scale, father

\footnotetext{
${ }^{1} \mathrm{Bu}$ çalışma ikinci yazarın danışmanlığındaki birinci yazarın yüksek lisans tezinden üretilmiştir.
} 


\section{GíRiş}

Babanın çocuğun gelişimindeki rolü ve önemi yanıtlanmaya çalışılan ve incelenmeye değer bir sorudur. Bugün artan baba araştırmalarına rağmen, ebeveynler üzerine yapılan incelemelerin çoğunluğu sadece anneleri içerdiğinden babalarla ilgili halen öğrenecek çok şeyin olduğu vurgulanmaktadır (Cabrera, 2019).

Baba katılımının çocuğun gelişiminin çeşitli yönlerine olumlu etkisini ortaya koyan çok sayıda araştırma bulgusu söz konusudur. Uluslararası literatürde yer alan baba çalışmalarının sonuçlarını değerlendirerek hazırlanan bir rapor, babanın ebeveynliğe aktif katılımının sadece çocuğun duygusal, fiziksel, bilişsel ve sosyal gelişimini değil aynı zamanda annenin ve babanın kendisinin de ruhsal ve bedensel iyi oluşunu olumlu yönde etkilediğini göstermektedir (Levtov, Van der Gaag, Greene, Kaufman ve Barker 2015, s. 42-45). Yakın dönemli boylamsal bir araştırmada ise babaların çocukluk dönemindeki paylaşılan etkinlikler gibi niceliksel ve ilişki kalitesi, babanın çocuğa yönelik olumlu davranışları gibi niteliksel katılımının uzun dönemli etkileri ele alınmıştır. Çocukluk döneminde baba katılımının erkek çocukların yetişkinlik döneminde, fizyolojik stresi düzenleme sistemi üzerinde doğrudan etkisi olduğu saptanmıştır (Choi, Kim, Capaldi ve Snodgrass, 2021). Çocuklarıyla aynı evde ve ayrı yaşayan babaların karşılaştırıldığ 1 bir başka araştırmada ise aynı evde yaşayan babaların baba katılımının, ergen kız çocuklarının risk davranışlarına yönelimiyle negatif yönde ilişkili olduğu sonucu elde edilmiştir (Cryer-Coupet, Dorsey, Lemmons ve Hope, 2020).

Son dönemde, baba katılım araştırmalarının sayısı arttıkça, farklı yaş gruplarıyla yapılan genel gelişimsel olumlu sonuçları içeren araştırmaların yanında (Slaughter ve Nagoshi, 2020) baba katılımının daha spesifik gruplar (örn. yeni doğan yoğun bakım servisinde kalan çocuklar, pediatri kliniğindeki kronik hastalar gibi) üzerindeki etkilerinin incelendiği araştırmalara rastlanmaktadır (Hearn, Clarkson ve Day, 2019; Taylor, Fredericks, Janisse ve Cousino, 2020). Öte yandan, baba katılımının bir değişken olarak ele alındığı model denemeleriyle bu çalışmaların farklı etnik yapıları ve kültürler arası karşılaştırmaları içerdiği görülmektedir (Chong ve Savitri, 2020; Cryer-Coupet ve diğerleri, 2020; Kume, 2015; Williams, 2013). Özellikle, son dönemde kültürlerarası karşılaştırmaları içeren araştırmaların derlendiği çalışmalar da yoğunluk kazanmıştır (Roopnarine, 2015; Schwalb, Schwalb ve Lamb, 2013). Ülkemizde ise sınırlı sayıda olmakla birlikte baba katılımının ve babalık rollerinin kavramlaştırılmasına, niteliğinin, belirleyicilerinin ve gelişimsel sonuçlarının incelenmesine yönelik çalışmaların olduğu görülmektedir (Ana Çocuk Eğitim Vakfı [AÇEV], 2017; Aslan, 2020; Karabulut, 2017; Karabulut ve Şendil, 2018; Karaduman ve Çı̆̆ 2020; Özyeşer-Cinel, 2021). Mevcut çalışma ile sınırlı sayıda olan baba katılım araştırmalarına bir ölçüm aracıyla katkı sağlamak hedeflenmektedir.

Başlangıcından bugüne baba araştırmalarındaki en büyük zorluklardan biri baba katılımının boyutlarının tanımlanması ve kavramsallaştırılmasıdır. Babalar üzerine yapılan araştırmalarda babalık rolü, babalık kültürü, baba katılımı kavramları zaman zaman birbirinin yerine kullanılabilmektedir (Erdem, 2020). Baba katılımı kavramı ilk kez Lamb, Pleck, Charnov ve Levine tarafından (1985) baba çocuk ilişkisinin düzeyini ve boyutlarını tanımlamak amaciyla geliştirilmiştir. Babanın rolünün "eve ekmek getiren" ya da "cinsiyet rol modeli" gibi tek bir role indirgenip indirgenmeyeceği, babanın zamansal olarak ölçülebilen niceliksel katılımının mı yoksa niteliksel katılımının mı önemli olduğu, katılımın doğrudan ya da dolaylı yönlerinin ne olduğu yanıtlanmaya çalışılan sorulardır (Lamb, 2010). Bugün babanın çocuğun gelişimindeki rolünün ve katılımının bireysel (anne, baba, çocuk özellikleri), ailesel (anne baba evlilik ilişkisi), bağlamsal (kültürel beklentiler, ekonomik durum, sosyal politikalar vb.) faktörlerden etkilenen çok yönlü ve çok boyutlu karmaşık bir yap1 olduğu genel kabul görmektedir (Doherty, Kouneski ve Erikson, 1998; Lamb, 2000; Lamb ve Tamis-Lemonde, 
2004; Parke, 1996; 2000). Baba katılım yapısının dolaylı ya da doğrudan yönlerini ve çeşitli boyutlarını farklı ölçüm araçlarıyla değerlendirmeye yönelik çabalar ise devam etmektedir (Carlson, 2006; Hofferth, 2003; Pleck, 2010).

Baba katılım ölçümlerine kaynaklık eden iki modelden bahsedilebilir. Birincisi yukarıda sözü edilen Lamb ve Pleck modeli olarak bilinen ve temel bileşenleri "doğrudan temas", "erişilebilirlilik" ve "sorumluluk" olarak kavramlaştırılan katılım yapısıdır (Lamb ve diğerleri, 1985). Zaman içinde yapılan araştırmalar sonucunda bu yaklaşım "sıcaklık/duyarlılık" ve "kontrol/izleme" gibi çeşitli boyutlar eklenerek revize edilmiştir (Pleck, 2010). İkinci modelde ise baba katılımının, duygusal, bilişsel ve davranışsal alanları kapsayan çok boyutlu bir yapı olduğu ileri sürülmüştür. Çocuğun gelişimine etki eden 15 kategorik yol tanımlanarak çeşitli etkinlikler belirlenmiştir (Hawkins ve Palkovitz, 1999; Palkovitz, 1997). Bu model için geliştirilen ölçüm aracı, baba katılımının algılanma seviyesinin babalar tarafından değerlendirilmesini olanaklı kılmaktadır (Hawkins, Bradford, Palkovitz, Christiansen, Day ve Call, 2002). İkinci modelden hareket etmekle birlikte babanın perspektifi yerine çocuğun fenomenolojik algısını merkeze alan bir yaklaşımla geliştirilen bir başka baba katılım ölçüm aracı ise Finley ve Schwartz'a (2004) aittir.

Finley ve Schwartz'a (2004, s.145) göre “uzun vadede çocuğun bugün ve gelecek davranışlarına etki eden ve önemli olan, çocuğun ailesiyle ilişkisine dönük onun zihninde oluşan "tortular" dır". Bir başka deyişle ilişkinin gerçekte ne olduğu değil bu gerçeğin çocuk tarafından nasıl algılandığıdır. Bu nedenle, çocukluk ve ergenlikte baba katılım algısını retrospektif olarak ölçmeye dönük bir ölçüm aracı ileri sürmüş ve "mevcut katılım" ve "arzu edilen katılım" olmak üzere iki düzeyi değerlendiren baba katılım ölçekleri geliştirmişlerdir. Üniversite öğrencileriyle gerçekleştirdikleri araştırmalarda geçmişe dönük baba katılım algısının onların psikolojik iyi oluşları ve psikososyal uyumlarıyla güçlü bir biçimde ilişkili olduğuna yönelik sonuçlara ulaşmışlardır (Finley ve Schwartz, 2007; 2010). Yürüttükleri bu araştırmalarda baba katılımının üç boyutunu (yakınlık, mevcut ve arzu edilen) üç ölçüm aracıyla değerlendirmişler ve aynı zamanda farklı babalık biçimlerini (birden fazla baba olması ya da baba figürü olarak tanımladıkları başka kişilerin olması gibi) gözeten bir baba anketi uygulamışlardır. Çocuğun babayla olan yakınlığını değerlendiren ilk ölçüm aracı Finley (1998) tarafından geliştirilmiş ve bu ölçek Kuzucu ve Özdemir (2013) tarafindan Baba Katılım Ölçeği adıyla Türkçeye uyarlanmıştır.

Kuşkusuz bugüne kadar gerçekleştirilmiş olan baba araştırmalarında babanın rolünü, çocukla ilişkisini ve katılımının farklı boyutlarını ölçmeye dönük çeşitli ölçme araçları Türkçeye uyarlanmış (Ünlü, 2010; Kuzucu ve Özdemir, 2013) ya da geliştirilmiştir (Sımsıkı ve Şendil, 2014). Bu çalışmaların daha çok erken yaş grubu çocuğu olan babaları kapsadığı ve babanın bildirimlerine dayandığı ya da ergen yaş grubu için geçerli olduğu görülmektedir.

Yakın dönemli bir başka ölçek uyarlama çalışması Uzun'a (2020) aittir. Söz konusu araştırmada ise baba çocuk ilişkisini değerlendirmek üzere Dick'in (2004) geliştirmiş olduğu Babalık Ölçeğinin 14-18 yaş aralığındaki çocuklar için geçerlik ve güvenirliği test edilmiştir. Bu uyarlama çalışması değerlendirildiğinde, gerek babanın katılımı dışında farklı boyutları içeren 69 maddeden oluşması, gerekse kapsadığı yaş aralığı nedeniyle; üniversite öğrencileriyle gerçekleştirilecek baba katılım çalışmaları için ölçek ihtiyacının devam ettiği söylenebilir. Mevcut çalışmada ise uyarlaması hedeflenen baba katılım ölçeklerinin, üniversite öğrencilerine yönelik olmasının, "mevcut" ve "arzu edilen" olmak üzere baba katılımının iki düzeyini ölçmeye olanak sağlamasının; retrospektif olmasının ve madde sayısının azlığının diğer baba katılım ölçüm araçlarından ayırt edici yönleri olduğunu söylemek mümkündür. Çocuklukta ve Ergenlikte Mevcut Baba Katılım Algısı Ölçeği, Erkman (2009) tarafından Baba İlgisi Ölçeği olarak Türkçeye uyarlanmış olsa da ölçeğin faktör analizleri yapılarak faktörleri belirlenmemiştir. Yukarıda sıralanan gerekçelerle ve üniversite öğrencileriyle yürütülecek baba 
araştırmalarında bir ölçüm aracı ihtiyacından hareketle bu çalışmanın amacı, Çocuklukta ve Ergenlikte Mevcut ve Arzu Edilen Baba Katılım Algısı Ölçeklerinin geçerlik ve güvenirliğinin test edilmesi ve Türkçeye uyarlanmasıdır.

\section{YÖNTEM}

\section{Araştırmanın Modeli}

Betimsel araştırma modeliyle yürütülen bu araştırmada, Finley ve Schwartz (2004) tarafından geliştirilen, Çocuklukta ve Ergenlikte Mevcut ve Arzu Edilen Baba Katılım Algısı ölçeklerinin Türkçeye uyarlanarak geçerlik ve güvenirliği test edilmiştir.

\section{Çalışma Grubu}

$\mathrm{Bu}$ araştırmanın örneklemi, üniversite öğrencisi olma; annenin ve babanın evli ve bir arada yaşıyor olması; gönüllü olma ölçütleri doğrultusunda ve uygunluk prensibine göre oluşturulmuştur. Katılımcılara, uygunluk prensibi doğrultusunda; araştırmacının sınıf ortamında uygulama yapmasına izin veren üniversiteler ve öğretim üyeleri yoluyla ulaşılmıştır. Böylece araştırma, İstanbul Üniversitesi Fen-Edebiyat Fakültesi Psikoloji Bölümü ve İktisadi ve İdari Bilimler Fakültesi Ekonomi Bölümü, İstanbul Teknik Üniversitesi İşletme Fakültesi Ekonomi Bölümü, Eskişehir Osmangazi Üniversitesi Mühendislik Fakültesi Elektrik Elektronik Bölümü, Kocaeli Üniversitesi İktisadi ve İdari Bilimler Fakültesi Çalışma Ekonomisi Bölümü ve Marmara Üniversitesi Yabancı Diller Hazırlık sınıfı olmak üzere toplamda 370 öğrenciyle gerçekleştirilmiştir.

Örneklem büyüklüğü belirlenirken geçerlik ve güvenirliği test edilen ölçüm aracının madde sayısı dikkate alınmıştır. Örneklem büyüklüğünün madde sayısının 10 katı ve üzeri olması gerekliliğinden hareket edilmiştir (Kline, 1994). Ancak, ölçütlere uymayan; form ve ölçeklerinde eksik bilgiler olan 83 öğrenci çalışmaya dahil edilmemiştir. Böylece 18-29 yaş aralığında, yaş ortalaması 21,53 $(\mathrm{S}= \pm 1,8)$ olan 152 kadın ve 135 erkek olmak üzere toplam 287 üniversite öğrencisi bu araştırmanın örneklemini oluşturmuştur. Tablo 1'de demografik bilgiler yer almaktadır. 
Tablo 1.Araştırmada Yer Alan Öğrencilere Ait Demografik Bilgiler

\begin{tabular}{lrr}
\hline & N & \% \\
\hline Üniversite Öğrencileri & 152 & 53,00 \\
Kadın & 135 & 47,00 \\
Erkek & 287 & 100,00 \\
Toplam & 5 & \\
\hline Baba Eğitim & 57 & 1,75 \\
Okur yazar değil & 25 & 23,35 \\
İlkokul & 101 & 8,71 \\
Ortaokul & 9 & 35,19 \\
Lise & 78 & 3,14 \\
Önlisans & 2 & 27,18 \\
Lisans ve Üstü & 287 & 0,68 \\
Eksik bilgi & & 100,00 \\
Toplam & 12 & \\
& 116 & 4,20 \\
\hline Anne Eğitim & 29 & 40,42 \\
Okur yazar değil & 76 & 10,10 \\
İkokul & 6 & 26,48 \\
Ortaokul & 46 & 2,10 \\
Lise & 2 & 16,02 \\
Önlisans & 287 & 0,68 \\
Lisans ve Üstü & & 100,00 \\
Eksik bilgi & 25 & 8,71 \\
Toplam & 231 & 80,49 \\
\hline Ekonomik Durum & 31 & 10,80 \\
Düşük & 287 & 100,00 \\
Orta & & \\
Yüksek & & \\
Toplam & & \\
\hline
\end{tabular}

\section{Verilerin Toplanması}

Uygulama, 2015-2016 bahar döneminde dersten sorumlu öğretim elemanının izin verdiği sınıflarda ders saatleri içerisinde yapılmıştır. Derse öğretim elemanı ile birlikte girilmiş, öğrencilere çalışmanın amacı anlatılmış, katılımın gönüllülük ilkesine göre olacağ 1 ve dağıtılan form ve ölçekleri doldurmalarının yaklaşık 15-20 dakikalarını alacağı belirtilmiştir. Öncelikle öğrencilerden bilgilendirilmiş onam formunu doldurmaları istenmiştir; hiçbir sınıfta katılmayı reddeden öğrenci olmamıştır. Uygulama süresi 10-20 dakika arasında değişmiştir. Uyarlanması hedeflenen ölçeğin test tekrar test güvenirliğini ölçmek için ölçek İstanbul Üniversitesi'nde uygulamaya katılan 50 üniversite öğrencisine 15 gün arayla yeniden uygulanmıştır.

\section{Veri Toplama Araçları}

Araştırmanın verileri Kişisel Bilgi Formu ve Baba Anketi kullanılarak toplanmıştır. Baba Anketi, Finley ve Schwartz (2004) tarafindan Baba Katılım Ölçeği; Çocuklukta ve Ergenlikte Mevcut Baba Katılım Algısı Ölçeği ve Çocuklukta ve Ergenlikte Arzu Edilen Baba Katılım Algısı Ölçeği olmak üzere üç ölçeği içerecek şekilde kullanılmaktadır.

\section{Bilgilendirilmiş Onam Formu}

$\mathrm{Bu}$ form araştırmada yer alacak katılımcılara çalışmanın temel amacı ve işlemi hakkında bilgi vermek ve onların gönüllü katılım ve onaylarını sağlamak amacıyla oluşturulmuştur. 


\section{Kişisel Bilgi Formu}

Araştırmacılar tarafından oluşturulan Kişisel Bilgi Formu, katılımcıların yaş, cinsiyet, ekonomik durum ve anne babanın eğitimleri gibi demografik bilgileri içermektedir. Form biri açık uçlu, dördü çoktan seçmeli olmak üzere toplam beş sorudan oluşmaktadır.

\section{Baba Katılım Ölçeği (BKÖ) (Nurturant Fathering Scale)}

$\mathrm{Bu}$ ölçek babanın duygusal desteğini ve yakınlığını genç yetişkinlerin bakış açısından değerlendirmek amacıyla Finley (1998) tarafından geliştirilmiştir ve dokuz maddeden oluşmaktadır. Her bir madde beşli likert üzerinden ve soruların içeriğine bağlı olarak farklı ifadelerle değerlendirilmektedir (oldukça çok-hiç, her zaman-hiçbir zaman, oldukça yakın-hiç yakın değil, çok iyi-çok kötü, mükemmel-iyi değil). Yapılan iki çalışmada Cronbach alfa iç tutarlık katsayıs1 .88 ile .90 olarak bildirilmiştir (Finley, 1998; Williams ve Finley, 1997; akt. Kuzucu ve Özdemir 2013). Finley ve Schwartz (2004) tarafından gerçekleştirilen açımlayıcı faktör analizi ölçeğin, varyansın \%69,4'ünü açıklayan ve öz değeri 6.24 olan tek faktörlü bir yapıya sahip olduğunu göstermiştir. Aynı çalışmada, maddelerin faktör yükleri .76 ve daha yukarı olup $\mathrm{R}^{2}$ değerleri .57 ve .83 arasında değişmektedir. Doğrulayıcı faktör analizinde elde edilen uyum değerlerinin yeterli olduğu bulgulanmıştır (akt. Kuzucu ve Özdemir, 2013).

Ölçeğin Türkçe uyarlaması Kuzucu ve Özdemir (2013) tarafından 15-17 yaş arasındaki ergenler üzerinde yapılmıştır. Bu uyarlama çalışmasında, ölçeğin Cronbach alfa iç tutarlılık katsayısının .88 olduğu belirlenmiştir. Ölçeğin varyansın \%54'ünü açıklayan ve öz değeri 4.9 olan orijinal ölçekte olduğu gibi tek faktörlü bir yapıya sahip olduğu ortaya konmuştur. Uyarlama çalışmasında $\mathrm{R}^{2}$ değerlerine bakıldığında örtük değişken tarafindan maddelerde açıklanan varyans miktarının .36 ile .77 arasında değiştiği ve bir çok maddenin açıklanan varyansının .50’nin üzerinde olduğu belirtilmiştir (Kuzucu ve Özdemir, 2013).

$\mathrm{Bu}$ ölçek toplam puan üzerinden değerlendirilmektedir. Alınabilecek en yüksek toplam puan 45 olup, düşük oranda duygusal desteği, en düşük toplam puan 9 olup yüksek oranda duygusal desteği göstermektedir.

Mevcut çalışmada ölçeğin Cronbach alfa iç tutarlık katsayısı .89 olarak hesaplanmıştır. Ölçek, güvenirliği test etmek için aynı zamanda Çocuklukta ve Ergenlikte Mevcut Baba Katılım Algısı Ölçeği için eş ölçek olarak kullanılmıştır.

\section{Çocuklukta ve Ergenlikte Baba Katılım Algısı Ölçekleri}

Finley ve Schwartz (2004) çocuğu merkeze alan bir yaklaşımla, çocuğun yaşamının ve gelişiminin çeşitli yönlerinde (zihinsel, duygusal, sosyal vb.) baba katılım algısını "mevcut" ve "arzu edilen" olmak üzere iki farklı düzeyde değerlendirebilmek amacıyla iki kısa formdan oluşan baba katılım ölçekleri geliştirmişlerdir. Bu araştırmada da babanın katılım algısının mevcut ve arzu edilen düzeyleri iki ayrı ölçekle ve bir arada ölçülmüştür. Araştırmacılar, katılımcıların algısını ölçtüklerini söylemelerine rağmen bu durum ölçek adına yansımamıştır. Bu çalışmada ölçek adı hem mevcut hem de arzu edilen düzeyleri ve algıyı da içerecek şekilde "Çocuklukta ve Ergenlikte Mevcut Baba Katılım Algısı Ölçeği” ve "Çocuklukta ve Ergenlikte Arzu Edilen Baba Katılım Algısı Ölçeği” olarak adlandırılmıştır. Aşağıda her iki ölçek tanımlanmış ve geçerlik ve güvenirlik analizlerine yer verilmiştir.

\section{Çocuklukta ve Ergenlikte Mevcut Baba Katılım Algısı Ölçeği (ÇEMBKAÖ) (Reported Father Involvement)}

$\mathrm{Bu}$ ölçek, çocuğun yaşamının ve gelişiminin çeşitli yönlerinde mevcut baba katılım algısını ölçmeyi amaçlamaktadır (Finley ve Schwartz, 2004). Açımlayıcı ve doğrulayıcı faktör analizleri sonucunda ölçeğin 20 maddeli ve üç faktöre sahip olduğu görülmüştür. Bu faktörler, sekiz maddeyi kapsayan Duygusal Destekleyici Katılım (Expressive Involvement) (Bakım 
vermek, Arkadaşlık, İlgi ve Etkinlik Paylaşma, Duygusal Gelişim, Sosyal Gelişim, Manevi Gelişim, Fiziksel Gelişim, Boş Zaman Eğlence) $(\alpha=.93)$; sekiz maddeyi kapsayan Araçsal Katılım (Instrumental Involvement) (Koruyucu Olma, Terbiye etme, Para Sağlama, Okul/Ev Ödevleri, Etik/Ahlaki Gelişim, Sorumluluk Geliştirme, Mesleki Gelişim, Bağımsızlık Geliştirme) $(\alpha=.91)$ ve dört maddeyi kapsayan Yol Gösterici Katılım (Mentoring/advising involvement) (Zihinsel Gelişim, Yetkinlik Geliştirme, Tavsiye Verme, Öğretici ve Yol gösterici olma) $(\alpha=.90)$ olarak adlandırılmıştır. Mevcut Katılım düzeyi 5'li likert (Her zaman ilgiliydihiçbir zaman ilgili değildi) kullanılarak toplam puan üzerinden değerlendirilmekte, değerler 20100 arasında değişmektedir. Yüksek puan babanın yüksek katılım oranını, düşük puan düşük katılım oranını göstermektedir (Finley ve Schwartz, 2004).

\section{Çocuklukta ve Ergenlikte Arzu Edilen Baba Katılım Algısı Ölçeği (ÇEABKAÖ) (Desired Father Involvement)}

Ölçek, çocuğun, hayatının ve gelişiminin çeşitli yönlerinde babasının katılımının mevcut durumla karşılaştırıldığında ne düzeyde olmasını arzuladığını ölçebilmek amacıyla Finley ve Schwartz (2004) tarafından geliştirilmiştir. Bu ölçek, "Çocuklukta ve Ergenlikte Mevcut Baba Katılım Algısı Ölçeğiyle" paralel bir biçimde, birebir yapılandırılmış 20 maddeyi içermektedir. Arzu Edilen Katılım Düzeyi 5'li likert üzerinden, 5 "Çok daha fazla ilgilenmesini İsterdim", 1 "çok daha az ilgilenmesini isterdim" ve 3 "Gerektiği kadar ilgilendi" şeklinde değerlendirilmektedir. Açımlayıcı faktör analizi sonucunda iki faktörlü bir yapı ortaya çıkmıştır. Birinci faktör, "Arzu Edilen Duygusal Destekleyici Katılım (Expressive Desired Involvement)" olarak isimlendirilmiş olup, toplam varyansın \%31,6'sını açıklamış ve 11 maddeden oluşmuştur (Zihinsel gelişim, duygusal gelişim, sosyal gelişim, manevi gelişim, fiziksel gelişim, boş zaman/eğlence/oyun, öğretici ve yol gösterici olma, bakım verme, okul/ev ödevleri). İkinci faktör ise "Arzu Edilen Araçsal Katılım (Instrumental Desired Involvement)" olarak isimlendirilmiş olup, toplam varyansın \%29.4'ünü açıklamış ve 9 maddeden oluşmuştur (Etik/ahlaki gelişim, mesleki gelişim, sorumluluk geliştirme, bağımsızlık geliştirme, yetkinlik geliştirme, para sağlama, koruyucu olma, tavsiye verme, terbiye etme). Madde faktör yükleri ilk faktör için .40 - .72 arasında, ikinci faktör için .48 -.73 arasında değişkenlik göstermiştir. Cronbach alfa değerleri Arzu Edilen Duygusal Destekleyici Katılım faktörü için $\alpha=.93$, Arzu Edilen Araçsal Katılım faktörü için $\alpha=.92$ ve toplam ölçek için $\alpha=.96$ olarak belirlenmiştir (Finley ve Schwartz, 2004). Ölçek toplam puan üzerinden değerlendirilmekte, yüksek puan yüksek oranda katılım arzusunu belirtirken, düşük puan arzu edilenden fazla oranda katılım anlamina gelmektedir (Finley ve Schwartz, 2004, 2007).

\section{Verilerin Analizi}

Katılımcıların demografik özelliklerine ait tanımlayıcı bulgular frekans dağılımları hesaplanarak elde edilmiştir. Çocuklukta ve Ergenlikte Mevcut Baba Katılım Algısı ve Çocukluk ve Ergenlikte Arzu Edilen Baba Katılım Algısı Ölçeklerinin yapı geçerliğini ölçmek için oblik döndürme yönteminin kullanıldığı açımlayıcı faktör analizi yapılmıştır. Açımlayıcı faktör analizinin ardından elde edilen iki ve üç faktörlü ölçek yapılarının uyum değerlerini karşılaştırmak amacıyla yapısal eşitlik modeli kapsamında doğrulayıcı faktör analizi gerçekleştirilmiştir.

Ölçeklerin ölçüt geçerliği ve test tekrar test korelasyonları için Pearson momentler çarpımı korelasyon analizi kullanılmış, güvenirliğiyle ilgi olarak Cronbach alfa iç tutarlılık katsayısı hesaplanmıştır. 


\section{BULGULAR VE TARTIŞMA}

Bu bölümde Çocukluk ve Ergenlikte Baba Katılım ölçeklerinin geçerlik ve güvenirliklerini test etme amacı doğrultusunda çeviri işlemi, yapı geçerliği ile güvenirlik analizlerine ilişkin bulgular yer almaktadır.

\section{Çeviri İşlemi}

Çocukluk ve Ergenlikte Baba Katılım Ölçekleri'nin Türkçeye uyarlama çalışmaları için öncelikle ölçeği geliştiren araştırmacılardan izin istenip onayları alınmıştır. İki boyuttan oluşan ölçeklerin Mevcut Katılım Düzeyi'nin Erkman (2009) tarafından faktör analizi yapılmadan sadece güvenirliği test edilerek Türkçeye Baba İlgisi Ölçeği olarak kazandırılmış olduğu ancak Arzu Edilen Katılım Düzeyi Boyutunun uyarlama çalışmasının hiç yapılmadığı görülmüştür. $\mathrm{Bu}$ çalışma kapsamında öncelikle ölçeklerin bu boyutunun Türkçeye çevirisi, çeviri-yeniden çeviri yoluyla gerçekleştirilmiştir. Bu amaçla 20 maddeden oluşan ölçek başta araştırmacı olmak üzere, iki alan uzmanı tarafından ayrı ayrı Türkçeye çevrilmiştir. Araştırmacı tarafından yapılan çevirinin uygunluğu diğer iki çalışmayla karşılaştırılarak test edilmiştir. Türkçeye çevrilen ölçek taslağı iyi derecede İngilizce bilen bir alan uzmanı tarafından tekrar İngilizceye çevrilmiştir. Ölçeğin İngilizceye dönüştürülmüş hali ve Türkçe çevirisi anlam birliği açısından araştırmacı ve alan uzmanları tarafından tekrar değerlendirilmiştir. Olumlu değerlendirmelerin ardından ölçeğin anlaşılırlığını ve işlerliğini test etmek amacıyla 10 üniversite öğrencisi üzerinde pilot çalışma yürütülmüş ve elde edilen sonuçlar bu araştırmanın verilerine dahil edilmemiştir. Tüm değerlendirmelerin ardından ölçeğin geçerlik güvenirlik çalışması için uygun hale geldiği görüşüne ulaşılmıştır.

\section{Çocukluk ve Ergenlikte Mevcut Baba Katılım Algısı Ölçeğinin Geçerlik Analizleri}

\section{Madde Analizi}

Toplam 287 kişiye uygulanan bu ölçüm aracının madde analizi aşamasında öncelikle madde toplam puan korelasyonları hesaplanmıştır. Maddelerin korelasyon katsayıları 52 ile .79 arasında değişmiştir. Analiz sonucunda bütün maddelerin toplam puanla olan ilişkilerinin kabul edilebilir düzeyde olduğu görülmüştür.

\section{Açımlayıcı Faktör Analizi}

Ölçek, yapı geçerliliği kapsamında temel eksen boyutlandırması ve oblik döndürme yönteminin kullanıldığı açımlayıcı faktör analizine tabi tutulmuştur. Açımlayıcı faktör analizi neticesinde, özdeğeri 1'in üzerinde olan iki faktör tespit edilmiştir. Madde yükü .30'un altında olan 19. madde (okul/ev ödevleri); çift yüklendiği için 1. (zihinsel gelişim), 7. (Mesleki Gelişim) ve 10. (Yetkinlik Geliştirme) maddeler ölçekten çıkartılmıştır.

Ölçeğin iki faktörlü bu halinde 1. faktörde toplam varyansın yaklaşık \%50'sini açıklayan ve Araçsal Katılım (instrumental) boyutunu içeren toplam 9 madde; 2. faktörde toplam varyansın yaklaşık \%10'unu açıklayan ve Duygusal Destekleyici katılım boyutunu ölçen 7 madde olduğu gözlemlenmiştir. Her bir faktörün isimleri, özdeğerleri, Cronbach alfa iç tutarlılık sayıları, faktör yükleri, varyans değerleri ile ortalama ve standart sapmaları Tablo 2'de verilmiştir. 
Tablo 2. Çocukluk ve Ergenlikte Mevcut Baba Katılım Algısı Ölçeği Faktörler, Maddeler, Faktör Yükleri, Oblik Döndürmeden Sonraki Genel Varyans Değerleri

\begin{tabular}{lcc}
\hline Araçsal Katılım & Faktör Yükleri & Varyans Değerleri \\
Toplam 9 madde. Özdeğer: 8,114 Cronbach & & \\
Alfa: .91, varyans: \%50 & & .587 \\
\hline 4 Etik Ahlaki Gelişim & .658 & .591 \\
5 Manevi Gelişim & .564 & .588 \\
8 Sorumluluk Geliştirme & .677 & .452 \\
12 Para Sağlama & .598 & .675 \\
14 Öğretici yol Gösterici Olma & .585 & .465 \\
15 Bakım Verme & .486 & .577 \\
16 Koruyucu olma & .729 & .601 \\
17 Tavsiye Verme & .758 & .537 \\
18 Terbiye Etme & .886 & \\
\hline Duygusal Destekleyici Katılım & Faktör Yükleri & Varyans Değerleri \\
Toplam 7 madde. Özdeğer: 1,628, varyans: & & .638 \\
\%10, Cronbach Alfa: .90 & & .540 \\
\hline 2 Duygusal Gelişim & .727 & .432 \\
3 Sosyal Gelişim & .785 & .471 \\
6 Fiziksel Gelişim & .460 & .619 \\
9 Bağımsızlık Geliştirme & .512 & .645 \\
11 Boş zaman/Eğlence/Oyun & .884 & .652 \\
13 İlgi ve Etkinlik Paylaşma & .767 & \\
20 Arkadaşlı/:Dostluk Etme & .733 & \\
\hline
\end{tabular}

Yapılan son madde analizi neticesinde de birinci faktörün madde toplam puan korelasyonlarının .59 - .73 (12 ve 17 maddeler) ikinci faktörde .57- .76 (6. ve 2. maddeler) olduğu tespit edilmiştir. Sonuçta bütün maddelerin toplam puanla olan ilişkilerinin kabul edilebilir düzeyde olduğu görülmüştür.

Araştırmanın diğer basamağında orijinal ölçek (Finley ve Schwartz, 2004) üç faktörlü yapıya sahip olduğu için elde edilen veriler yeniden temel eksen boyutlandırması ve oblik döndürme yöntemi kullanılarak bu defa üç faktörlü yapıya zorlanmış ve her iki yapının uyum değerlerini karşılaştırabilmek amacıyla yapısal eşitlik modeli kapsamında doğrulayıcı faktör analizi yürütülmüştür. Ölçeğin iki ve üç faktörlü yapısının doğrulayıcı faktör analizleri sonuçları aşağıda sunulmuştur. 


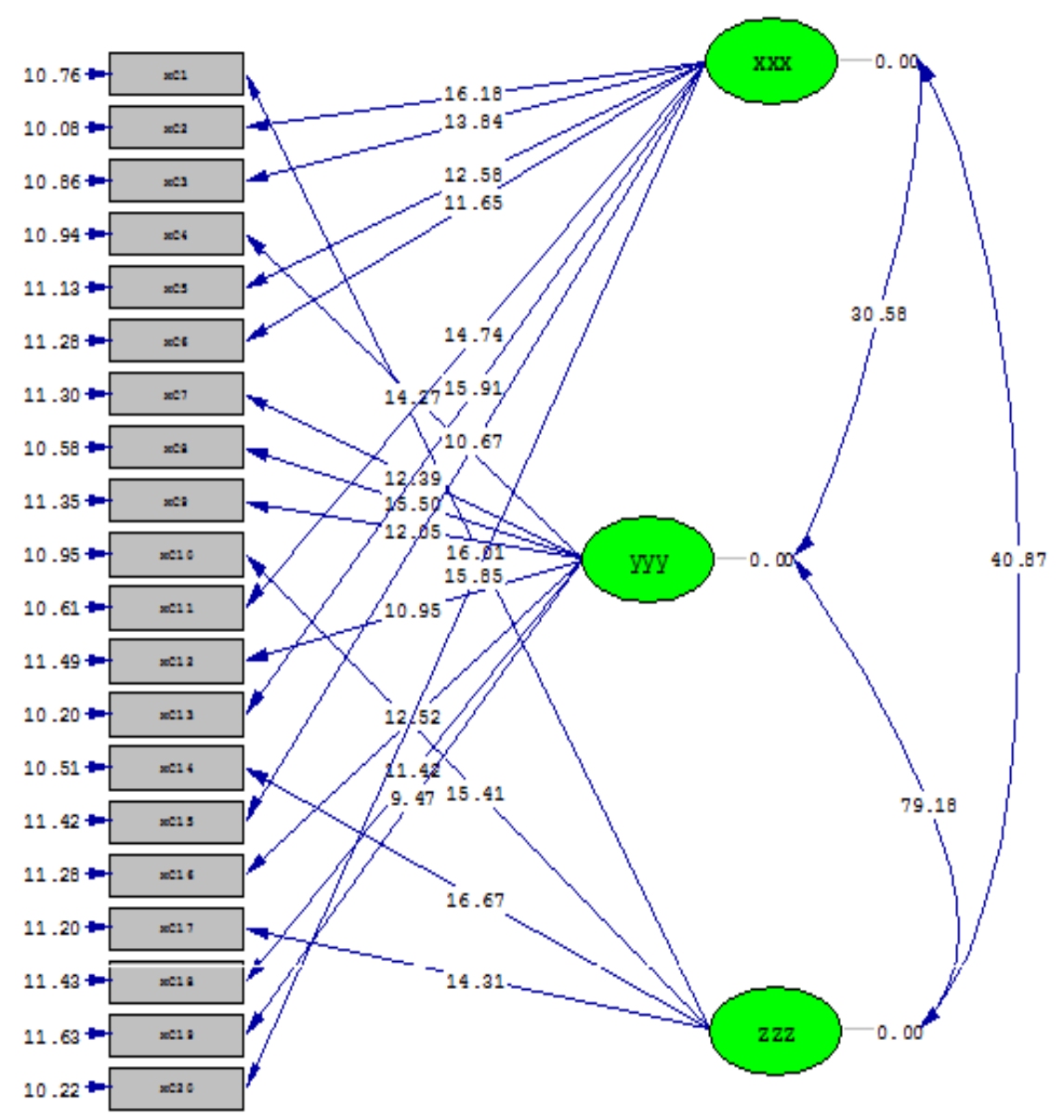

Chi-Square $=759.92, \mathrm{df}=167, \mathrm{P}-\mathrm{value}=0.00000, \mathrm{RMSEA}=0.111$

Şekil 1. Üç Faktörlü Yapının Doğrulayıcı Faktör Analizi Sonuçları 


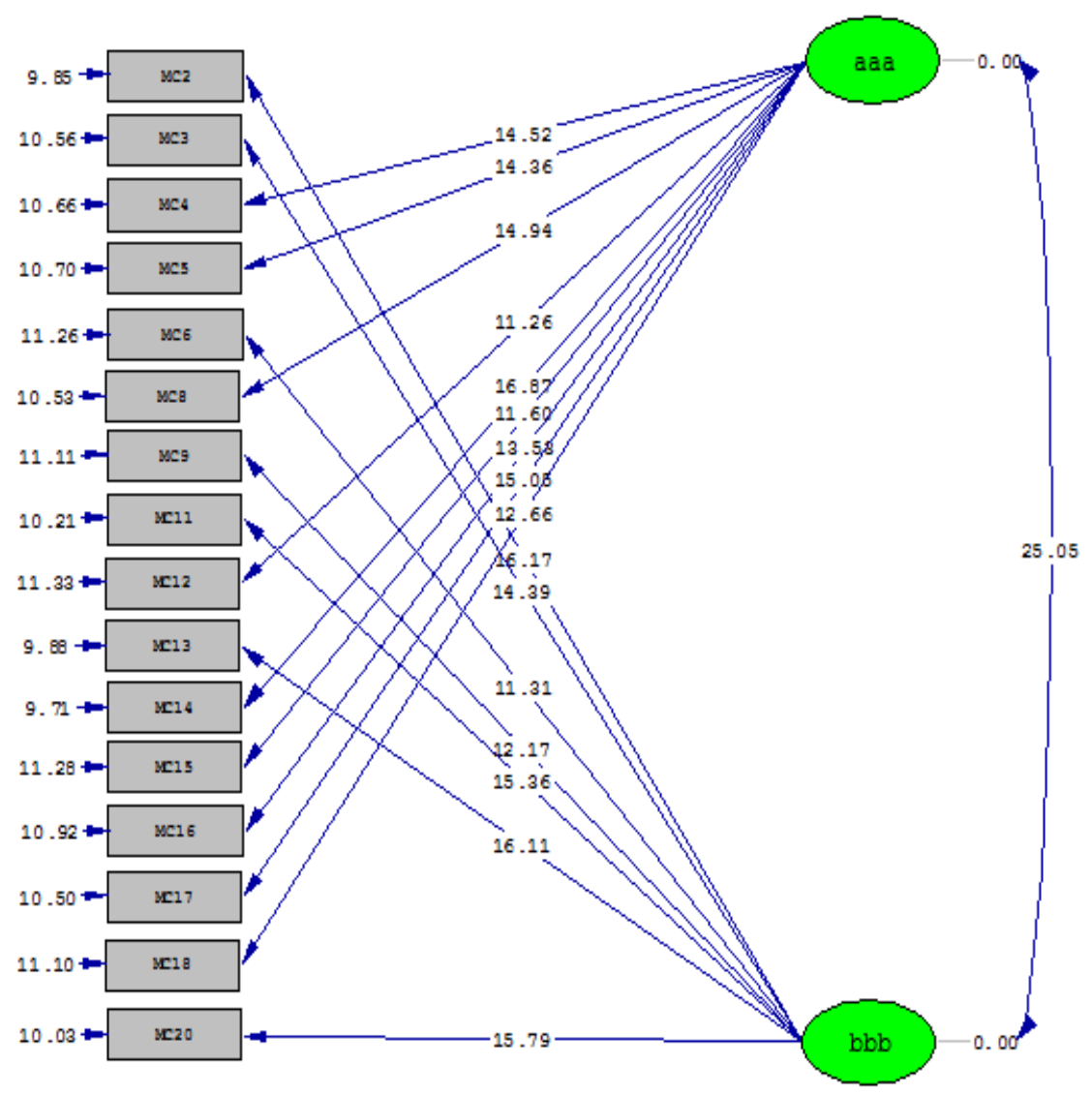

Chi-Square $=360.00, \mathrm{df}=103, \mathrm{P}-\mathrm{value}=0.00000, \mathrm{RMSEA}=0.093$

Şekil 2. Uyarlanmış İki Faktörlü Yapının Doğrulayıcı Faktör Analizi Sonuçları

İki ve üç faktörlü yapılar için gerçekleştirilen doğrulayıcı faktör analizi neticesinde iki faktörlü yapının uyum değerlerinin hem de karşılaştırmalı uyum endekslerinin üç faktörlü yapıya kıyasla daha kabul edilebilir olduğu tespit edilmiştir. Her iki yapının uyum değerleri ile karşılaştırmalı endeks katsayıları ve modifikasyon sayıları Tablo 3'de görülebilir.

Tablo 3.Üç ve İki Faktörlü Yapıların Uyum Değerleri İle Karşılaştırmalı Endeks Katsayıları ve Modifikasyon Sayıları

\begin{tabular}{lcccccc} 
& GFI & sRMR & AGFI & CFI & RMSEA & X $^{2} / \mathrm{df}$ \\
\hline 3Faktörlü & 0.79 & 0.069 & 0.74 & 0.86 & 0.111 & 4.55 \\
\hline Uyarlanmış & 0.86 & 0.059 & 0.82 & 0.91 & 0.093 & 3.49 \\
2 Faktörlü & & & & & &
\end{tabular}

GFI:Uyum İyiliği İndeksi sRMR:Standardize edilmiş kök kare artık AGFI: Ayarlanmış Uyum İyiliği İndeksi CFI:Karşılaştırmalı Uyum İndeksi RMSEA: Yaklaşık Hataların Ortalama Karekökü 


\section{Ölçüt bağımlı geçerlik}

Yine yapı geçerliği kapsamında, ölçeğin eş ölçek olarak nitelendirilebilecek Baba Katılım Ölçeği arasındaki korelasyon incelenmiştir. İki ölçek arasındaki korelasyon değeri .80 ( p<.01) olarak hesaplanmıştır.

\section{Güvenirlik Analizi}

Ölçeğin test-tekrar test güvenirliğini belirlemek için ölçek 50 üniversite öğrencisine iki hafta arayla iki kez uygulanmıştır. Bu iki uygulama arasındaki korelasyon .89 ( p<.01) olarak hesaplanmıştır.Yukarıda belirtilen analiz sonuçları, 16 maddeli; Araçsal Katılım ve Duygusal Destekleyici Katılım olmak üzere iki faktörlü olan Çocukluk ve Ergenlikte Mevcut Baba Katılım Algısı Ölçeğinin geçerli ve güvenilir olduğunu ortaya koymuştur.

\section{Çocuklukta ve Ergenlikte Arzu Edilen Baba Katılım Algısı Ölçeğinin Geçerlik Analizleri}

\section{Madde analizi}

Toplam 287 kişiye uygulanan bu ölçüm aracının madde analiz aşamasında ilk olarak madde toplam puan korelasyonları hesaplanmıştır. Analiz sonucunda 2. maddenin toplam madde korelasyonu .20'nin altında çıkmış ve bu madde ölçekten çıkarıldıktan sonra tekrar yürütülen analiz neticesinde geriye kalan 19 maddenin toplam puanla olan ilişkilerinin .44 ile .72 arasında değiştiği ve bu değerlerin kabul edilebilir düzeyde olduğu görülmüştür.

\section{Açımlayıcı faktör analizi}

Ölçek, yapı geçerliliği kapsamında temel eksen boyutlandırması ve oblik döndürme yönteminin kullanıldığı açımlayıcı faktör analizine tabi tutulmuştur. Bu analiz neticesinde özdeğeri 1'in üzerinde olan üç faktör tespit edilmiştir. Madde yükü .30'un altında olduğu için 6. madde ölçekten çıkarılmıştır.

Ölçeğin 3 faktörlü son halinde 1. faktörde toplam varyansın yaklaşık \%46'sını açıklayan ve Arzu Edilen Araçsal Katılım boyutunu içeren toplam 9 madde; 2. faktörde toplam varyansın yaklaşık \%10'unu açıklayan ve Arzu Edilen Duygusal Destekleyici Katılım boyutunu ölçen 6 madde, ve 3. faktörde toplam varyansın yaklaşık \%7'sini açıklayan ve Arzu Edilen Özerkleştirici Katılım boyutunu ölçen 3 madde olduğu gözlemlenmiştir. Her bir faktörün isimleri, özdeğerleri, Cronbach alfa iç tutarlılık sayıları, faktör yükleri, ortak varyans değerleri ile ortalama ve standart sapmaları Tablo 4'de gösterilmiştir. 
Tablo 4. Çocuklukta Ve Ergenlikte Arzu Edilen Baba Katılım Algısı Ölçeği Faktörler, Maddeler, Faktör Yükleri, Oblik Döndürmeden Sonraki Varyans Değerleri

\begin{tabular}{|c|c|c|}
\hline $\begin{array}{l}\text { Arzu Edilen Araçsal Katılım } \\
\text { Toplam } 9 \text { madde. Özdeğer:8,303, varyans: } \\
\% 46 \text {, Cronbach Alfa: .92 }\end{array}$ & $\begin{array}{c}\text { Faktör } \\
\text { Yükleri }\end{array}$ & Varyans Değerleri \\
\hline 4 Etik/ahlaki gelişim & .701 & .690 \\
\hline 5 Manevi gelişim & .659 & .588 \\
\hline 7 Mesleki gelişim & .447 & .475 \\
\hline 12 Para sağlama & .748 & .573 \\
\hline 14 Yol gösterici olma & .586 & .660 \\
\hline 15 Bakım verme & .669 & .579 \\
\hline 16 Koruyucu olma & .846 & .643 \\
\hline 17 Tavsiye verme & .767 & .609 \\
\hline 18 Terbiye etme & .815 & .624 \\
\hline $\begin{array}{l}\text { Arzu Edilen Duygusal Destekleyici } \\
\text { Katılım } \\
\text { Toplam } 6 \text { madde. Özdeğer:1,945, varyans: } \\
\% 10 \text {, cronbach alfa: } .84\end{array}$ & $\begin{array}{c}\text { Faktör } \\
\text { Yükleri }\end{array}$ & Varyans Değerleri \\
\hline 1 Zihinsel gelişim & .439 & .490 \\
\hline 3 Sosyal gelişim & .591 & .582 \\
\hline 11 Boş zaman/eğlence/Oyun & .808 & .525 \\
\hline 13 İlgi ve etkinlik paylaşma & .769 & .590 \\
\hline $19 \mathrm{Okul} / \mathrm{ev}$ ödevleri & .505 & .401 \\
\hline 20 Arkadaşlik/dostluk etme & .665 & .512 \\
\hline $\begin{array}{l}\text { Arzu Edilen Özerkleştirici Katılım } \\
\text { Toplam } 3 \text { madde. Özdeğer: } 1,383 \text {, varyans: } \\
\% 7 \text {, cronbach alfa: } .86\end{array}$ & $\begin{array}{c}\text { Faktör } \\
\text { Yükleri }\end{array}$ & Varyans Değerleri \\
\hline 8 Sorumluluk geliştirme & .559 & .664 \\
\hline 9 Bağımsızlık geliştirme & .742 & .598 \\
\hline 10 Yetkinlik geliştirme & .729 & .647 \\
\hline
\end{tabular}

Yapılan son madde analizi neticesinde de birinci faktörde madde toplam puan korelasyonlarının .56 - .75 (7. ve 16. maddeler), ikinci faktörde .50- .70 (19. ve 13. maddeler) ve üçüncü faktörde .69 - . 76 (8. ve 10.maddeler) olduğu tespit edilmiştir.

Ancak orijinal ölçeğin iki boyutlu olması ve bu çalışmada Mevcut Katılım düzeyinden de iki faktörlü bir yapı elde edilmiş olması nedeniyle yeniden temel eksen boyutlandırması ve oblik döndürme yöntemi kullanılarak bu defa iki faktöre zorlanarak bir doğrulayıcı faktör analizi yürütülmüştür. $\mathrm{Bu}$ faktör analizi neticesinde 6 ve 19. maddeler ortak varyans değeri .30'un altında olduğu için ölçekten çıkarılmıştır. Analiz sonucunda birinci faktörde toplam varyansın \%45'ini açıklayan ve Arzu Edilen Araçsal Katılım boyutunu ölçen 12 madde, ikinci faktörde toplam varyansın \%10'unu açıklayan ve Arzu Edilen Duygusal Destekleyici Katılım boyutunu ölçen 5 madde ile iki faktörlü bir yapı elde edilmiştir. Bu iki faktörlü doğrulayıcı faktör analizine ilişkin betimsel bulgular da Tablo 5'de sunulmuştur. Yapılan son madde analizi neticesinde de birinci faktörün madde toplam puan korelasyonlarının .57 - .75 (9. ve 14 . maddeler), ikinci faktörde .54-.72 (1. ve 13. maddeler) olduğu saptanmıştır. 
Tablo 5. Çocuklukta ve Ergenlikte Arzu Edilen Baba Katılım Algısı Ölçeği Faktörler, Maddeler, Faktör Yükleri, Oblik Döndürmeden Sonraki Varyans Değerleri

\begin{tabular}{|c|c|c|}
\hline $\begin{array}{l}\text { Arzu Edilen Araçsal Katılım } \\
\text { Toplam } 12 \text { madde. Özdeğer: } 8,567 \text {, } \\
\text { varyans: } \% 45 \text {, cronbach alfa:.93 }\end{array}$ & Faktör Yükleri & Varyans Değerleri \\
\hline 4 Etik/ahlaki gelişim & .807 & .699 \\
\hline 5 Manevi gelişim & .742 & .571 \\
\hline 7 Mesleki gelişim & .553 & .465 \\
\hline 8 Sorumluluk geliştirme & .703 & .673 \\
\hline 9 Bağımsızlık geliştirme & .426 & .594 \\
\hline 10 Yetkinlik geliştirme & .507 & .650 \\
\hline 12 Para sağlama & .727 & .592 \\
\hline 14 Öğretici / yol gösterici olma & 679 & .651 \\
\hline 15 Bakım verme & .669 & .563 \\
\hline 16 Koruyucu olma & .791 & .633 \\
\hline 17 Tavsiye verme & .777 & .604 \\
\hline 18 Terbiye etme & .869 & .629 \\
\hline $\begin{array}{l}\text { Arzu Edilen Duygusal Destekleyici } \\
\text { Katılım }\end{array}$ & Faktör Yükleri & Varyans Değerleri \\
\hline $\begin{array}{l}\text { Toplam } 5 \text { madde. Özdeğer: } 1,981 \\
\text { Varyans: } \% 10 \text { cronbach alpha:. } 84\end{array}$ & & \\
\hline 1 Zihinsel gelişim & .467 & .472 \\
\hline 3 Sosyal gelişim & .687 & .595 \\
\hline 11 Boş zaman eğlence & .738 & .504 \\
\hline 13 İlgi etkinlik paylaşma & .797 & .589 \\
\hline 20 Arkadaşl1k dostluk Etme & .669 & .516 \\
\hline
\end{tabular}

Araştırmanın diğer basamağında orjinal ölçek (Finley ve Schwartz, 2004) iki faktörlü olduğu için ikiye zorlanmış olan yapı (Şekil 3), Lisrel'e dahil edilmiş ve daha iyi uyum değerleri elde elde edilmesi amacıyla uyarlanarak Şekil 4'te gösterilen uyarlanmış iki faktörlü yapı elde edilmiştir. İlk elde edilen iki faktörlü yapı, uyarlanmış iki faktörlü yapı ve üç faktörlü yapının 
uyum değerlerini karşılaştırabilmek amacıyla yapısal eşitlik modeli kapsamında doğrulayıcı faktör analizi yapılmıştır. Bu analiz sonuçları aşağıda sunulmuştur.

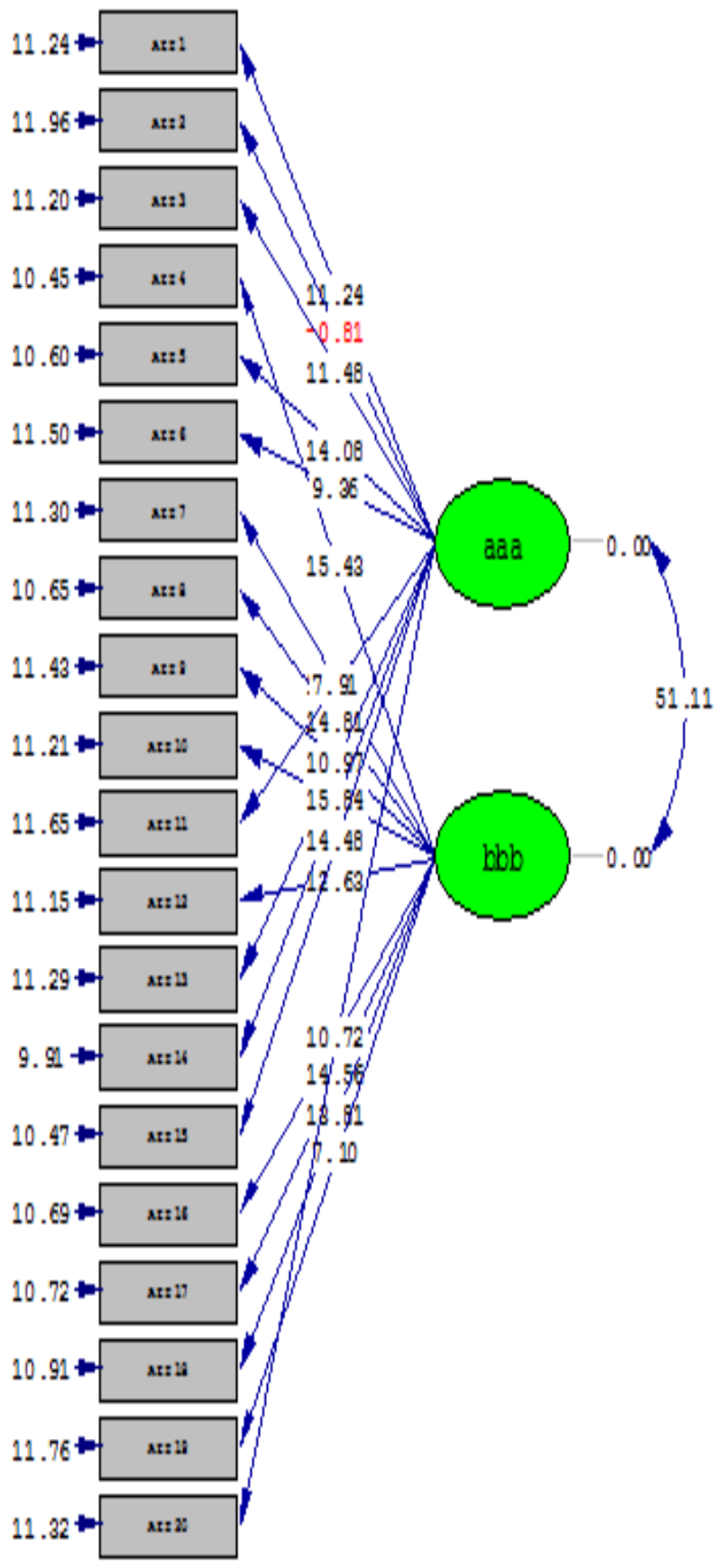

Şekil 3. İki faktörlü yapının doğrulayıcı faktör analizi sonuçları 


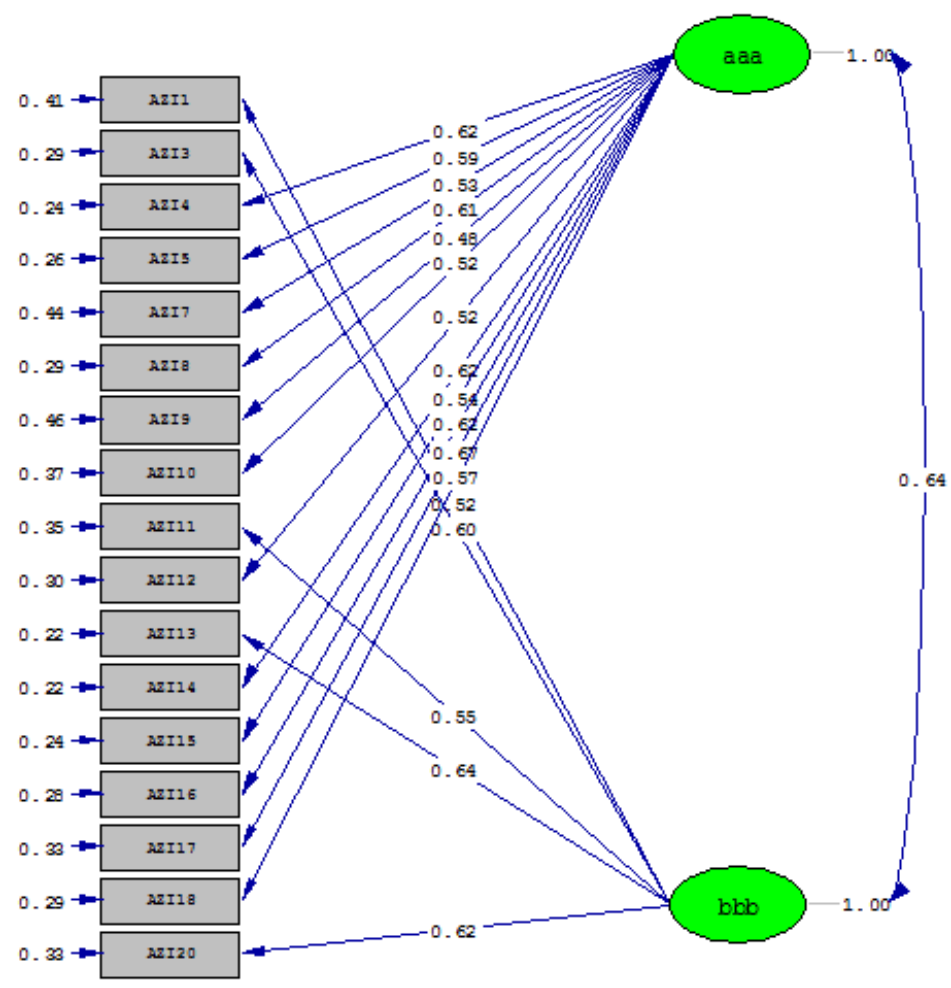

Chi-Square $=693.67, \mathrm{df}=118, \mathrm{P}-\mathrm{value}=0.00000, \mathrm{RMSEA}=0.131$

Şekil 4. Uyarlanmış iki faktörlü yapının doğrulayıcı faktör analizi sonuçları

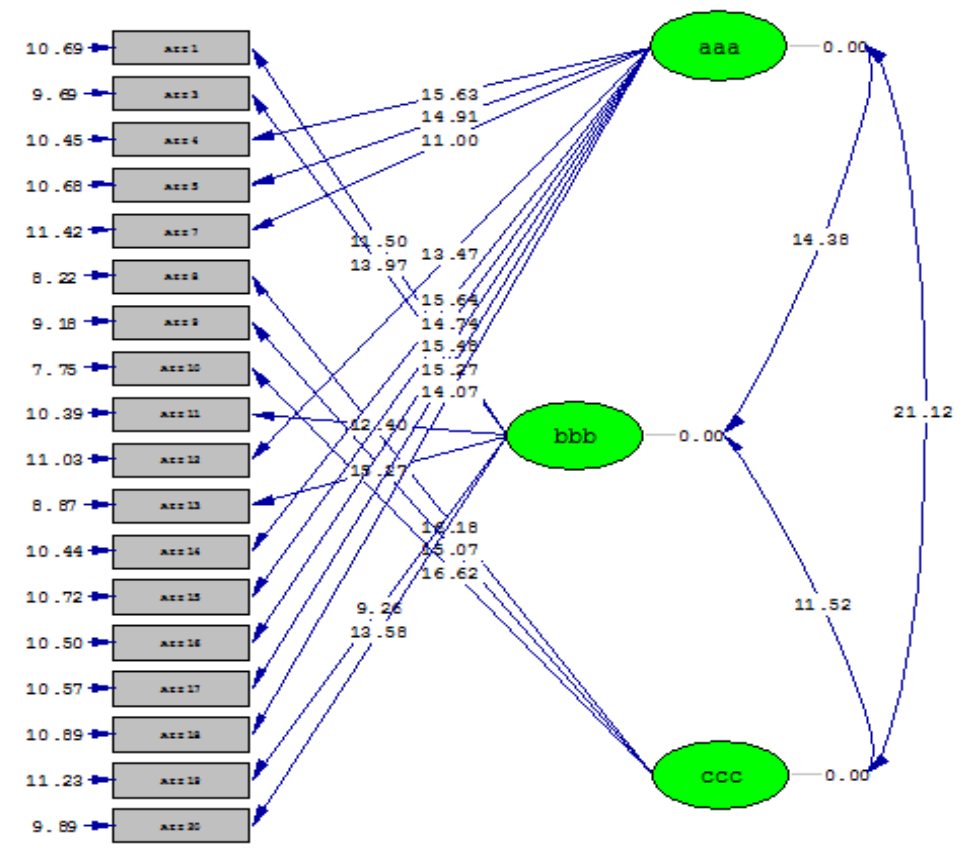

Chi-Square $=544.62, d f=132, \mathrm{P}$-value $=0.00000$, RMSEA $=0.105$

Şekil 5. Uyarlanmış üç faktörlü yapının doğrulayıcı faktör analizi sonuçları 
Her üç yapı için gerçekleştirilen doğrulayıcı faktör analizi neticesinde üç faktörlü yapının hem uyum değerlerinin hem de karşılaştırmalı uyum endekslerinin ilk elde edilen iki faktörlü yapıya ve uyarlanmış iki faktörlü yapıya kıyasla daha kabul edilebilir olduğu tespit edilmiştir. Her üç yapının uyum değerleri ile karşılaştırmalı endeks katsayıları ve modifikasyon sayıları Tablo 6' da görülebilir.

Tablo 6. İki Faktörlü; Uyarlanmış İki ve Üç Faktörlü Yapıların Uyum Değerleri İle Karşılaştırmalı Endeks Katsayıları ve Modifikasyon Sayıları

\begin{tabular}{lllllll}
\hline & GFI & sRMR & AGFI & CFI & RMSEA & X $^{2} / \mathrm{df}$ \\
\hline 2 Faktörlü & 0.70 & 0.088 & 0.63 & 0.74 & 0.146 & 7.12 \\
\hline $\begin{array}{l}\text { Uyarlanmış 3 } \\
\text { Faktörlü }\end{array}$ & 0.83 & 0.072 & 0.77 & 0.87 & 0.105 & 4.12 \\
\hline $\begin{array}{l}\text { Uyarlanmış 2 } \\
\text { Faktörlü }\end{array}$ & 0.78 & 0.078 & 0.71 & 0.83 & 0.131 & 5.87 \\
\hline
\end{tabular}

\section{Güvenirlik analizi}

Ölçeğin güvenirlik analizleri kapsamında ise ölçeğin test-tekrar test güvenirliğini belirlemek için ölçek 50 üniversite öğrencisine iki hafta arayla iki kez uygulanmıştır. Bu iki uygulama arasındaki korelasyon $.62(\mathrm{p}<.01)$ olarak hesaplanmıştır. Sonuç olarak, 18 maddeli ve Araçsal Arzu Edilen Katılım, Duygusal Destekleyici Arzu Edilen Katılım ve Özerkleştirici Arzu Edilen Katılım isimli üç faktörü olan bu ölçeğin geçerli ve güvenilir olduğu görülmüştür.

\section{Tartışma}

$\mathrm{Bu}$ çalışmanın amacı, üniversite öğrencileriyle yürütülecek baba katılım araştırmalarına bir ölçüm aracıyla katkı sağlamaktır. Üniversite öğrencilerinin baba katılım algısını mevcut ve arzu edilen iki düzeyiyle ölçmeye olanak tanıyan baba katılım ölçeklerinin (Finley ve Schwartz, 2004) bu alandaki eksikliği gidereceği düşünülmüştür.

$\mathrm{Bu}$ amaç doğrultusunda, öncelikle Çocuklukta ve Ergenlikte Mevcut Baba Katılım Algısı Ölçeğinin geçerlik ve güvenirliği test edilmiştir. Orijinal ölçek 20 maddeden ve üç faktörlü yapıdan oluşurken (Finley ve Schwartz, 2004), mevcut çalışmada yürütülen açımlayıcı ve doğrulayıcı faktör analizi sonucunda ölçeğin 16 maddeli ve iki faktörlü bir yapıya sahip olduğu sonucuna varılmıştır. Araştırmacılar, faktörleri adlandırırken Parsons ve Bales'in (1955) çekirdek ailede anne ve baba rollerine ilişkin kavramsallaştırmalarından hareket etmişlerdir. Parsons ve Bales, 20. yüzyılın ortasında çekirdek ailenin rolünü ve işlevlerini inceledikleri çalışmalarında, babaların aile içindeki en temel işlev ve rolünün çocuğun dış dünyaya uyumunu sağlamak olduğunu dile getirmişlerdir. Bu temel rolü koruyucu olma, gelir getirme ve disiplini sağlama gibi yönleriyle araçsal (instrumental) olarak nitelendirmişlerdir. Öte yandan, çocuk bakımının merkezinde yer alan, babalara kıyasla çocukla evde daha fazla vakit geçiren annelerin temel rolü ise duygusal anlamda destekleyici, bütünleyici olmaktır. Parsons ve Bales'e (1955) ait bu yaklaşımı temel alarak Finley ve Schwartz (2004), çocuğun dış dünyaya uyumunu sağlamaya dönük rolünü -gelir sağlamak, koruyucu olmak ve terbiye etmek gibikapsayan faktör için araçsal katılım (instrumental involvement); çocukla yakın bir diyaloğu, duygu ve ifade paylaşımını içeren, duygusal entegrasyonunu sağlayan rolü -bakım vermek, paylaşılan etkinlikler, ilgiler- kapsayan faktör için duygusal destekleyici katılım (expressive involvement) kavramlarını kullanmışlardır (Finley ve Schwartz, 2004, 2006). Mevcut araştırmada elde edilen faktör dağılımlarına bakıldığında ise birinci faktör yapısı etik/ahlaki gelişim, manevi gelişim, sorumluluk geliştirme, para sağlama, öğretici yol gösterici olma, bakım verme, koruyucu olma, tavsiye verme, terbiye etme maddelerinden oluşmaktadır. $\mathrm{Bu}$ maddeler "bakım verme" (caregiving) haricinde, Parsons ve Bales'in (1955) yukarıda belirtilen işlevselci yaklaşımında tanımladığ 1 babanın çocuğun dış dünyaya uyumunu sağlamaya dönük araçsal rollerini içermektedir. Bu nedenle bu faktör yapısına, orijinal ölçekle de paralel olarak 
Araçsal Katılım (instrumental involvement) adı verilmiştir. "Bakım verme" maddesinin bu faktör yapısında yer almasının nedeninin, çeviriden kaynaklı olabileceği, babanın çocuğun günlük bakımına katılımından ziyade, "bakmak"2 fiili olarak anlaşılmış olabileceği düşünülmektedir. Ölçeğin ikinci faktör yapısı ise duygusal gelişim, sosyal gelişim, fiziksel gelişim, bağımsızlık geliştirme, boş zaman eğlence, ilgi/etkinlik paylaşma, arkadaşlık/dostluk etme maddelerini içermektedir. Bu faktör yapısında yer alan maddelerin "bağımsızlık geliştirme" maddesi haricinde orijinal ölçekle paralel bir seyir izlediği görülmektedir. Bu maddelerin, Parsons ve Bales'in (1955) anneler için tanımlamış olduğu çocukla daha fazla etkileşime girerek onu duygusal olarak destekleme işlevlerini kapsadığ 1 söylenebilir. Daha önce de belirtildiği gibi çocuklarla daha çok etkileşime giren ve bunu kendini daha çok ortaya koyarak, kendi duygularını daha çok ifade ederek yapan anneler için "expressive" lider kavramı kullanılmıştır (Parson ve Bales, 1955, s.315). Yukarıda da belirtildiği gibi orijinal ölçekte de bu faktör yapısı "expressive involvement" olarak adlandırılmıştır (Finley ve Schwartz, 2004). Bu çalışmada, "expressive"’3 kavramını Türkçeye tek bir kelimede anlaşılır bir biçimde çevirme güçlügü nedeniyle ikinci faktör yapısı "duygusal destekleyici katılım” olarak adlandırılmıştır. Elde edilen bu faktörlerin ilerleyen çalışmalarda baba katılımının niteliğini ve değişen yapısını incelemede katkı sağlayacağı düşünülmektedir. Nitekim, Finley ve Schwartz (2006), faktörlerden faydalanarak Parsons ve Bales'in (1955) savlarını yeniden değerlendirmiş, günümüz babalarının araçsal rolünü koruyup korumadığını, babaya ait rollerin değişime uğrayıp uğramadığını araştırmışlardır. Söz konusu araştırmada elde edilen sonuçlara göre günümüzde de babanın araçsal katılımının, duygusal destekleyici katılımının üzerinde olduğu görülmüştür (Finley ve Schwartz, 2006). Ülkemizde yürütülecek araştırmalarda da babalık rolündeki mevcut durumun ve değişimin izini sürmek için ölçeğin faktörleriyle de faydalı olacağı umulmaktadır.

Araştırmanın bir diğer aşamasında, Çocuklukta ve Ergenlikte Arzu Edilen Baba Katılım Algısı Ölçeğinin geçerlik ve güvenirliğini test etmek ve bu ölçeği Türkçeye uyarlamak amaciyla açımlayıcı ve doğrulayıcı faktör analizleri yürütülmüştür. $\mathrm{Bu}$ analizler sonucunda orijinal ölçeğin 20 maddeli ve iki faktörlü yapısına karşın, iki madde (duygusal gelişim ve fiziksel gelişim) uygun geçerlik değerlerine sahip olmadığı için çıkarılmış ve 18 maddeyi içeren üç faktörlü bir yapı elde edilmiştir. Faktör yapılarından birincisi, etik/ahlaki gelişim, manevi gelişim, mesleki gelişim, para sağlama, yol gösterici olma, bakım verme, koruyucu olma, tavsiye verme, terbiye etme maddelerini içeren Arzu Edilen Araçsal Katılımdır. İkincisi, zihinsel gelişim, sosyal gelişim, boş zaman/eğlence/oyun, ilgi ve etkinlik paylaşma, okul/ev ödevleri, arkadaşlık/dostluk etme maddelerini içeren Arzu Edilen Duygusal Destekleyici Katılımdır. Bu çalışmada orijinal ölçekten farklı olarak üçüncü bir faktör yapısı elde edilmiştir. $\mathrm{Bu}$ faktör yapısı, sorumluluk geliştirme, bağımsızlık geliştirme, yetkinlik geliştirme maddelerini içermektedir. Bu faktör yapısı, madde içeriklerine bakılarak Arzu Edilen Özerkleştirici Katılım olarak adlandırılmıştır. Bu maddelerin aynı faktör yapısı altında yer almasından yola çıkarak araştırmanın katılımcısı olan üniversite öğrencilerinin babalarından özerkleştirici bir katılım arzu ettiği ileri sürülebilir. Gelecekte yapılacak çalışmalarda ölçeğin bu faktörüyle, farklı katılımcılar üzerinde uygulanıp başka değişkenlerle ilişkisine bakmak bu varsayımı test edebilir.

Arzu Edilen Baba Katılım Algısı literatürde henüz yeni olan bir kavramdır ve ilk olarak Finley ve Schwartz (2004) tarafından ele alınmıştır. Farklı aile yapılarıyla yürüttükleri çalışmalarda

\footnotetext{
${ }^{2}$ Bakmak fiili, Türkçe'de beslemek geçindirmek anlamında kullanılabildiği gibi, ilgilenmek, gözetmek anlamında da kullanılmaktadır (Atatürk Kültür, Dil ve Tarih Yüksek Kurumu Türk Dil Kurumu. 1988).

${ }^{3}$ Expressive kavramının anlatan, dışavurumcu, anlatımcı, gösteren, etkileyici, anlatımsal, dışavurumsal, ifade eden gibi karşılıklarla Türkçe çevirisinin yapıldığı görülmektedir. (expressive (t.y.) Tureng online sözlük içinde. Erişim adresi https://tureng.com/tr/turkce-ingilizce/expressive
} 
arzu edilen baba katılım algısıyla ilişkili anlamlı sonuçlar elde etmişlerdir. Ailesi boşanmıș olan genç yetişkinlerin arzu edilen baba katılım algısı ile öznel iyi oluşu arasında anlamlı bir ilişki olduğunu bulgulamışlardır. Söz konusu araştırmada faktörlerde cinsiyet farklarına bakıldığında ise genç yetişkin kadınların babalarından daha fazla duygusal destekleyici katılım arzu ettiklerini saptamışlardır (Finley ve Schwartz, 2007). Yakın dönemli bir başka araştırmada ise kültür ve cinsiyet farkları araştırılmıştır. Endonezya' da yaşayan Endonezyalı ve göçmen Güney Koreli ergen yaş grubunun (15-18) mevcut ve arzu edilen baba katılım algıları arasında anlamlı farklılıklar görülmüştür. Araştırma sonuçları, Endonezya'lı gençlerin babalarından özellikle gelir sağlama alanında daha fazla katılım arzu ettiğini, Güney Koreli gençlerin ise tavsiye verme alanında en düşük düzeyde katılım arzuladığını göstermiştir (Chong ve Savitri, 2020). Yerli literatürde henüz arzu edilen katılım yapısıyla ilişkili çalışmalar mevcut değildir. Arzu edilen baba katılımını ölçmeye olanak tanıyan bu ölçeğin gerek farklı aile yapılarıyla gerekse cinsiyetler ve kültürler arası farkları ortaya koymaya dönük çalışmalara katkı sağlayacağı düşünülmektedir.

\section{SONUÇ}

$\mathrm{Bu}$ araştırmada ergenler ve genç yetişkinlerle yürütülecek baba katılım çalışmalarına katkı sağlamak amacıyla Finley ve Schwartz (2004) tarafindan geliştirilen "Mevcut Katılım" ve "Arzu Edilen Katılım” olmak üzere iki düzeyi ölçen Çocuklukta ve Ergenlikte Baba Katılım Ölçekleri Türkçeye uyarlanmış ve geçerliği ve güvenirliği test edilmiştir. Yürütülen analizler sonucunda "Çocuklukta ve Ergenlikte Mevcut Baba Katılım Algısı" ve Çocuklukta ve Ergenlikte Arzu Edilen Baba Katılım algısı" ölçeklerinin geçerli ve güvenilir olduğu saptanmıştır. Retrospektif bir ölçüm aracı olan bu ölçeklerle babanın gerçek katılımını ölçmek değil, çocuğun çocukluk ve ergenlik döneminde babanın katılımını ne şekilde algıladığını ortaya koyabilmek hedeflenmektedir. Baba katılımının geçmişe dönük olarak araştırılmasının ve boyutlarının saptanmasının nedeni zihinde kalan olumlu "tortular"'n gerçek durumun kendisinden daha önemli olduğu görüşüne dayalı fenomenolojik yaklaşımın benimsenmesidir (Finley ve Schwartz, 2004). Mevcut çalışmada uyarlanan ölçeklerin bu yaklaşımla hareket eden araştırmacılara yürüttükleri baba çalışmalarında katkı sağlayacağı düşünülmektedir.

Bu araştırma İstanbul, Kocaeli ve Eskişehir'de yer alan çeşitli üniversitelerden sınırlı sayıda üniversite öğrencisiyle gerçekleştirildiği için araştırma sonuçları bu üniversite öğrencileriyle sınırlıdır. Yine bu çalışmada olan bir başka sınırlılık araştırma katılımcılarının anne baba bir arada olan aile yapılarından gelmeleridir. Farklı aile yapılarından gelen daha geniş katılımlı bir araştırmada baba katılımının etkisini ve arzu edilen düzeyini ölçmek ve karşılaştırmak anlamlı ve farklı sonuçlar verebilir. Arzu edilen baba katılımının boyutlarını ölçebilmek, gelecekte özellikle boşanmış ailelerde yürütülecek çalışmalarda, çocukların ihtiyaçlarının tespit edilmesinde ve bu yönde geliştirilecek sosyal politikaların oluşturulmasında yarar sağlayabilir.

Her iki ölçek diğer ölçüm araçlarıyla birlikte kullanılarak üniversite öğrencilerinin, geçmişe dönük baba katılım algısının iyi oluş değişkenleriyle ilişkisi ve yaşamlarındaki izdüşümleri incelenebilir. Ölçekler sadece tamamı değil faktörleriyle de da babanın çocuğun yaşamındaki rollerinin "mevcut" ve "arzu edilen" yönlerinin tespit edilmesi ve bunların demografik değişkenlerle ilişkisinin araştırılması için kullanılabilir.

Ülkemizde babanın çocuğun gelişimine katılımını incelemeye dönük çalışmalar mevcut olmakla birlikte halen sınırlı sayıdadır. Özellikle ergenler ve genç yetişkinler üzerinde baba katılımıyla ilişkili yeterli çalışma söz konusu değildir. Baba katılım çalışmalarının artması, baba katılımının boyutlarının tespit edilmesi ve çocuğun psikolojik iyi oluşunun üzerindeki etkilerinin ortaya konması; babalara dönük gerçekleştirilecek eğitimlere ve dolaylı olarak annelerin desteklenmesine katkı sağlayacaktır. Bu araştırmanın bu yolda atılmış küçük bir adım olduğu umulmaktadır. 


\section{KAYNAKÇA}

Ana Çocuk Eğitim Vakfı (2017). Türkiye'de babalığı anlamak serisi I: Türkiye'de ilgili babalık ve beliryicileri ana raporu. Erişim adresi: http://www.acev.org/kaynaklarimiz/arastirmalarimiz-ve-yayinlarimiz

Atatürk Kültür, Dil ve Tarih Yüksek Kurumu Türk Dil Kurumu: Türkçe Sözlük. (1988). Ankara: Türk Dil Kurumu Yayınları.

Aslan, H. S. (2020). Çocuk gelişimi ve baba katılımı. Ş. Ünlü-Çetin (Ed.), Erken çocukluk gelişimi ve ĕgitiminde baba katılımı (2 bs., s.31-40) içinde. Ankara: Nobel Akademik Yayıncilik.

Büyüköztürk, Ş. (2002). Faktör analizi temel kavramlar ve ölçek geliştirmede kullanımı. Kuram ve Uygulamada Ë̆itim Yönetimi,32, 470-483.

Cabrera, N.(2019). Father involvement, father-child relationship and attachment in the early years. Attachment and Human Development. doi:10.1080/14616734.2019.1589070

Carlson, M. (2006). Family structure, father involvement, and adolescent behavioral outcomes. Journal of Marriage and Family, 68, 137-154.

Choi, J., Kim, H.K., Capaldi, D. M. ve Snodgrass, J. J. (2021). Long-term effects of father involvement in childhood on their son's physiological stress regulation system in adulthood. Developmental Psychobiology, 1-12. doi:10.1002/dev.22152

Chong, W.S. ve Savitri, L.S.Y. (2020). Comparisons of fathers's involvement in Korean immigrants and Indonesians: Gender and cultural differences. Advances in Social Science, Education and Humanities Research, 494, 471-485.

Cryer-Coupet, Q. R., Dorsey, M. S., Lemmons, B. P. ve Hope, E. C. (2020) Examining multiple dimensions of father involvement as predictors of risk taking intentions among black adolescent females. Children and Youth Services Review, 108, 1-10.

Dick, G.L. (2004). The fatherhood scale. Research on Social Work Practice, 14(2), 80-92.

Doherty, J. W, Kouneski, F. E., Erickson, F. M. (1998). Responsible fathering: An overwiev and conceptual framework. Journal of Marriage and the Family, 60, 277-292.

Erdem, S. (2020). Baba katılımı ölçümünde yorumsamacı yaklaşımın yeri. Akademik Hassasiyetler, 7(13), 407-430.

Erkman, F. (2009, Şubat). Relationship of perceived parental acceptance and perceived father involvement to resilience. The Society for Cross-Cultural Research 38. y1llik toplantısında sunulan bildiri, Las Vegas, Nevada, USA.

Fabrigar, L.R. ve Wegener, D.T. (2012). Exploratory factor analysis. New York, NY: Oxford University Press.

Finley, G.E. (1998). Parental age and parenting quality as perceived by late adolescents. Journal of Genetic Psychology, 159, 505-506.

Finley, G.E., ve Schwartz, S.J. (2004). The father involvement and nurturant fathering scales: Retrospective measures for adolescent and adult children. Educational and Psychological Measurement, 64(1), 143-164. doi: 101177/0013164403258453

Finley, G.E. ve Schwartz, S.J. (2006). Parsons and Bales revisited: Young adult children's characterization of fathering role. Psychology of Men\&Masculinity, 7(1), 42-55.

Finley, G. E., ve Schwartz, S.J. (2007). Father involvement and long-term young adults outcomes: The differential contributions of divorce and gender. Family Court Review, 45(4), 573-587. doi:101111/j.1744-1617.2007.00172.x

Finley, G.E. ve Schwartz, S.J. (2010). The divided world of the child: Divorce and long-term psychosocial adjustment. Family Court Review, 48 (3), 516-527. doi:101111/j.17441617.2010.01326.x

Hawkins, A.J. ve Palkovitz, R. (1999). Beyond ticks and clicks: The need for more diverse and broader conceptualizations and measures of father involvement. Journal of Mens's Studies, 8, 11-32. 
Hawkins, A.J., Bradford, K.P., Palkovitz, R., Christiansen, S.L., Day, R.D., Call, V.R.A. (2002). The inventory of father involvement: a pilot study of a new measure of father involvement. The Journal of Mens's Studies, 10 (2), 183-196.

Hearn, G., Clarkson, G. ve Day, M. (2019). The role of NICU in father involvement, beliefs and confidence: A follow up qualitative study. Advances in Neonatal Care, 20(1), 80-89. doi: 10.1097/ANC.0000000000000665

Hofferth, S. (2003). Race/ ethnic differences in father involvement in two-parent families: Culture, context, or economy? Journal of Family Issues, 24, 185-216.

Karabulut, H. (2017). Ergenlerin saldırgan davranışları, baba katılımı ve baba katılımının yordayıcıları arasındaki ilişkilerin incelenmesi. (Doktora Tezi). İstanbul Üniversitesi, Sosyal Bilimler Enstitüsü, İstanbul.

Karabulut, H. ve Şendil, G. (2018). Okul öncesi dönemdeki baba katılımının ebeveyn tutumlarına göre incelenmesi, Yaşam Becerileri Psikoloji Dergisi, 2/3, 143-154.

Karaduman, M.A. ve Çı̆̆g, O. (2020). Babaların çocukların hayatına katılımını etkileyen faktörler. Ş. Ünlü-Çetin (Ed.), Erken çocukluk gelişimi ve eğitiminde baba katılımı (2 bs., s.47-61) içinde. Ankara: Nobel Akademik Yayıncılık.

Kline, P. (1994). An easy guide to factor analysis. New York: Routledge.

Kume, T. (2015). The effect of father involvement in childcare on the psychological well-being of Adolescent: A cross cultural Study. New Male Studies: An International Journal, 4(1), 38-51.

Kuzucu, Y. ve Özdemir Y. (2013). Ergen ruh sağlığının anne ve baba katılımı açısından yordanmas1. Eğitim ve Bilim,38 (168), 96-112.

Lamb, M. (2000). The history of research on father involvement: An overview. Marriage \&Family Review, 29(2/3), 23-42.

Lamb, M. (2010). How do fathers influence children's development? Let me count the ways. M.E.Lamb (Ed.) The role of the father in child development ( 5 bs., s.1-26) içinde. Canada: John Wiley\&Sons.

Lamb, M.E., Pleck, J.H., Charnov, E., Levine, J.A. (1985). Paternal behavior in humans. American Zoologist. 25(3), 883-894. doi:10.1093/icb/25.3.883

Lamb, M. E. ve Tamis-Lemonda, C.S. 2004. The role of father: An introduction. M.E.Lamb. (Ed.) The role of father in child development içinde (s.1-31). Haboken, NJ, US; John Wiley \& Sons inc.

Levtov, R., van der Gaag, N., Grene, M., Kaufman ve M., Barker, G. (2015). State of the world's fathers. Washington, DC: Promunda, Rutgers, Save the children, Sanke Gender Justice and Men Engage Alliance.

Özyeşer-Cinel, N. (2021). Babaların ve büyükbabaların çocuklarının hayatına katılım durumları. Birey ve Toplum Sosyal Bilimler Dergisi, 11(1), 97-127. doi:10.20493/birtop.883288.

Palkovitz, R. (1997). Reconstructing "involvement": Advancing our understanding of good fathering. C. Tamis-Le Monda ve N. Cabrera (Ed), Handbook of father involvement: Multidisciplinary perpectives (s.119-140) içinde. Mahwah, NJ:Erbaum.

Parke, R. D. (1996). Fatherhood. Cambridge, MA: Harvard University Press.

Parke, R.D.(2000). Father involvement. Marriage\&Family Review, 29(2-3), 43-58.

Parsons, T. ve Robert, F.B. (1955). Family, socialization and interaction process. Glencoe III:Free press.

Pleck, J.H. (2010). Paternal involvement: revised conceptualization and theoretical linkages with children outcomes. M.E.Lamb (Ed.),The role of the father in child development (5 bs, s.58-93) içinde. Canada: John Wiley \& Sons

Roopnarine, J.L.(Ed.). (2015). Fathers across cultures: The importance, roles and diverse practices of dads. Santa Barbara, CA: Praeger. 
Schwalb, D., Schwalb, B.J., Lamb, M. (Ed.). (2013). Fathers in cultural context. Londra: Routledge.

Sımsıkı, H. ve Şendil, G. (2014). Baba katılım ölçeği'nin (BAKÖ) geliştirilmesi. Elektronik Sosyal Bilimler Dergisi, 13 (49), 104-123.

Slaughter, J. ve Nagoshi, C.T. (2020). Testing a contextual model of effects of father involvement on child behaviors. Child and Adolescent Social Work Journal, 37, 547556. doi:10.1007/s10560-020-00649-5

Şencan, H. (2005). Güvenilirlik ve geçerlilik. Ankara: Seçkin Yayınları.

Taylor, S.E., Fredericks, E.M., Janisse, H.C. ve Cousino, M. K. (2020). Systematic review of father involvement and child outcomes in pediatric chronic illness populations. Journal of Clinical Psychology in Medical Settings, 27, 89-106.doi:10.1007/s10880-019-096235.

Uzun, H. (2020). Babalık ölçeğinin Türkçeye uyarlanması: Geçerlik ve güvenirlik çalışması. Bingöl Üniversitesi Sosyal Bilimler Enstitüsü Dergisi, 10(20), 551-567.

Ünlü, Ş. (2010). Being fathered and being a father: examination of the general pattern of Turkish fathers' and their own fathers' involvement level for children between the ages 08. (Yüksek Lisans Tezi). Orta Doğu Teknik Üniversitesi, Sosyal Bilimler Enstitüsü, Ankara.

Williams, C, R. (2013). Father involvement and offspring's subjective well being in African Americans. ( Doktora Tezi).Tennessee State University, Tennessee. 